1996. - 108 с. 3. Дробов'язко П. І. Українська національна школа: витоки і сучасність / П. І. Дробов'язко. - К. : Академія, 1997. - 184 с. 4. Жигірь В. І. Зміст фахової підготовки вчителя обслуговуючої праці у вищому навчальному закладі: дис. ... канд. пед. наук : 13.00.01 / Вікторія Іванівна Жигірь; Бердянський держ. пед. ін-т ім. П. Д. Осипенко. - Бердянськ, 2001. - 207 с. 5. Знамеровська Н. П. Підготовка вчителя трудового навчання до розвитку художньо-конструкторських здібностей учнів основної школи : дис. ... канд. пед. наук : 13.00.02 / Наталія Павлівна Знамеровська ; Херсонський держ. пед. ун-т. - Херсон, 1999. - 231 с. б. Кобернік О. Модернізація підготовки майбутніх учителів / Олександр Кобернік// Трудова підготовка в закладах освіти. - 2004. - № 4. - С. 28-30. 7. Кузь В. Г. Учитель, школа пріоритети XXI ст. / В. Г. Кузь // Педагогіка і психологія. - 2002. - № 1-2. - С. 11-19.

УДК 377.031

Ірина Казанжи

\title{
СУЧАСНІ ПІДХОДИ ДО ПРОФЕСІЙНОЇ ПІДГОТОВКИ ВЧИТЕЛЯ ПОЧАТКОВОЇ ШКОЛИ
}

Казанжи І. В. Сучасні підходи до професійної підготовки вчителя початкової школи.

У статті проаналізовано сучасні підходи до професійної підготовки майбутніх учителів початкових класів, визначено умови модернізації підготовки вчителя початкової школи в системі вищої педагогічної освіти.

Ключові слова: професійна підготовка, інноваційна діяльність, фундаменталізація освіти, модернізація вищої педагогічної школи, персоналізований підхід.

Казанжи И. В. Современные подходы к профессиональной подготовке учителя начальной школы.

В статье проанализированы современные подходы к профессиональной подготовке будущих учителей начальних классов, определены условия модернизации подготовки учителя начальной школы в системе высшего педагогического образования.

Ключевые слова: профессиональная подготовка, инновационная деятельность, фундаментализация образования, модернизация высшей педагогической школы, персонализированный подход.

Kazanzhi I. V. Modern approaches to professional training future primary school teachers.

The article analyzes modern approaches to professional training future primary school teachers and defines conditions concerning the issue how to modernize training primary school teachers in the higher pedagogical education system.

Key words: professional training, innovative activity, fundamentalization of education, modernization of higher pedagogical school, personalized approach.

На сучасному етапі розвитку української держави помітно зросла увага до наукових досліджень, спрямованих на вдосконалення професійної підготовки майбутнього вчителя. Сучасна педагогічна наука спрямована на реформування системи освіти в Україні. Зміна життєдіяльності суспільства й розширення міжнародних зв'язків потребує від сучасної освіти підвищення рівня майбутніх 
фахівців, формування і розвитку психологічно грамотних і висококваліфікованих педагогів, зорієнтованих на особистість у навчанні й вихованні учнів.

Актуальність обраної теми зумовлена стратегічними завданнями державної політики, окресленими Національною доктриною розвитку освіти, відповідно до якої процес навчання й виховання повинен бути зорієнтований на ефективне оволодіння знаннями, різнобічний розвиток особистості студента, формування ініціативної i дієздатної людини 3 яскраво вираженою творчою індивідуальністю, самостійного громадянина демократичного суспільства. Сучасна система вищої педагогічної освіти спрямована на підготовку вчителя-професіонала, фахівця високого рівня, педагогалідера, педагога-організатора, який буде працювати творчо, здійснювати інноваційну освітню діяльність. Пошук нових підходів до підготовки сучасних фахівців початкової школи стає предметом вивчення представників педагогічної, психологічної та філософської науки України та інших країн світу.

Аналіз психологічної і педагогічної літератури показав, що нині створено суттєву теоретичну базу для вивчення проблем підготовки майбутніх учителів до професійної діяльності (І. Батракова, М. Берулова, М. Кларін, А. Кузнецов, Л. Кулікова, В. Сластьонін, А. Тряпіцина та ін.). Загальні питання формування особистості вчителя досліджували С. Архангельський, В. Войтко, С. Гончаренко, О. Дубасенюк, І. Зязюн, Н. Кічук, Н. Кузьміна, С. Сисоєва, Р. Хмелюк, Т. Яценко та ін.

Нове розуміння місця й ролі педагогічних дисциплін у професійному становленні майбутнього вчителя зумовило пошук нових підходів, чому присвячені роботи А. Алексюка, М. Ахметової, В. Бондаря, Г. Васяновича, С. Вітвицької, М. Гаврилової, А. Орлова, Н. Радіонової, В. Сенченко та ін. Проте питання формування системи професійних якостей майбутнього вчителя залишається актуальним. Адже, як зазначає Г. Васянович, нині «... педагогіка як наука в усьому світі зазнає сутнісних трансформацій, вона репрезентує найцікавіші результати соціальної гуманістики, культури. Водночас вона допомагає молодим людям знайти відповідь на питання про сенс життя, можливості розвитку і діяльності в умовах складного глобалізованого світу» [2].

Метою статті є визначення сучасних підходів до професійної підготовки майбутніх учителів початкової школи в наукових розвідках дослідників на сучасному етапі.

На початку нового тисячоліття, на думку С. Гончаренка, однією 3 найважливіших глобальних проблем розвитку освіти вважається ії фундаменталізація. Фундаменталізація освіти на сучасній основі має бути провідним імперативом освітніх реформ, означає спрямування іiі на узагальнені та універсальні знання, формування загальної культури i розвиток узагальнених способів мислення i діяльності. Науковець зазначає, що фундаменталізацію освіти слід розглядати як один 3 провідних загальнодидактичних принципів, покладених в основу сучасної багаторівневої освіти [3].

Фундаменталізація освіти висуває такі вимоги до сучасного рівня загальнонаукової та професійної компетентності майбутніх фахівців: володіння системою фундаментальних методологічних, спеціальних та культурологічних знань; здатність до ціннісно-смислового самовизначення в сучасному соціокультурному, інформаційному та професійному просторі; розвинуте теоретичне мислення; високий рівень професійної культури; володіння загальнонауковими професійно значущими методами наукового пізнання; готовність до культуротворчого діалогу; здатність на основі системного підходу проектувати пізнавальні інформаційні моделі, проблемні ситуації, а також моделі дослідницької, творчої діяльності з їх розв'язання [3]. 
Як зауважує Л. Онищук, головним завданням фундаментальної освіти $\epsilon$ створення оптимальних умов для розвитку гнучкого та багатогранного мислення, різних способів пізнання дійсності для виникнення внутрішньої потреби в саморозвитку та самоосвіті впродовж життя. Фундаментальна освіта стане дієвим інструментом формування наукової компетентності сучасного професіонала, каталізатором творчої свободи [6].

В останне десятиріччя значно збільшилась кількість наукових праць, присвячених проблемі інноваційного підходу до професійної підготовки майбутніх педагогів. М. Артюшина пропонує модель психолого-педагогічної підготовки, в основу якої покладено ідею про створення сприятливих умов для формування інноваційних властивостей особистості і відповідної поведінки. На думку М. Артюшиної, в основу концепції єдиної стратегії інноваційного розвитку студентів у професійній підготовці має бути закладена ідея інтеграції особистісних, соціальних і діяльнісних аспектів у реалізації єдиної стратегії інноваційного розвитку [1].

Для забезпечення підготовки особистості до інноваційної діяльності змісту навчання у вищій школі має бути притаманна проблемність, актуальність, образність; використання сучасних інформаційних засобів, комп'ютерних технологій. Важливими характеристиками змісту навчання для розвитку інноваційності має бути гнучкість та варіативність; активне залучення студентів до пошуку й опрацювання, особливо оновлення необхідної інформації, при цьому має заохочуватись особисте прийняття матеріалу, критична оцінка привнесення особистого досвіду, взаємонавчання [4].

Особлива функція освіти полягає в тому, що своїм змістом вона закладає базові, фундаментальні основи культури особистості. Персоналізований підхід в освіті, визнаний науковцями провідною тенденцією сучасної педагогічної теорії і практики, має на меті відкрити і розвинути особистість кожного студента, яку необхідно вивчати і знати в усіх її виявах. Обирати зміст, форми, цілі, методи і засоби виховання й навчання слід 3 урахуванням особистісних рис студентів. Педагог виходить 3 того, що тільки особистість може сформувати особистість, тому він повинен ураховувати і специфіку своєї особистості, працюючи над своїм особистим стилем педагогічної діяльності. Отже, під персоналізованим навчанням розуміють таке навчання, у процесі якого здійснюється персоналізація тих, хто вчиться, і тих, хто навчає. «Професійний розвиток невіддільний від особистісного - в основі одного й іншого лежить принцип саморозвитку, що детермінує здібність особистості перетворювати особисту життєдіяльність у предмет практичного перетворення, що веде до вищої форми життєдіяльності особистості - творчої самореалізації» [5]. Формування професійних якостей неможливо здійснити без персоналізованого підходу та його педагогічних принципів.

Основним результатом роботи зі студентами повинно стати повернення до сутності педагогічної професії, що передбачає опору на досягнення й успіх дитини, а також орієнтацію на оптимістичне сприймання нею світу в усій його складності й у відповідності зі стратегіями модернізації освіти.

Одним із аспектів організації супроводу студентів у педагогічному вищому навчальному закладі $€$ проблема вивчення індивідуальних здібностей майбутніх учителів і можливостей їх урахування в навчально-виховному процесі, однак ці дослідження не повинні звужуватися до індивідуального підходу. Майбутній учитель в умовах модернізації освіти розглядається як суб'єкт діяльності, як носій ініціативи, здібний до самопізнання і самовиховання.

Нині українська вища школа переживає період інтеграції в європейський освітній простір. Основні проблеми підготовки вчителів початкових класів у країнах 
Європи збігаються з тими проблемами, які розв'язують українські науковці. Викликає інтерес досвід підготовки вчителів початкових класів у Франції, що охоплює такі напрямки: мотивованість вибору педагогічної професії (майбутні студенти відбираються на основі спеціальної співбесіди); формування особистісних якостей учителя початкових класів за допомогою курсів за вибором; підготовка до розв'язання таких проблем, як шкільна адаптація дітей різних етнічних груп; практична спрямованість у викладанні психології та педагогіки.

Важливою умовою, що забезпечує ефективну професійну підготовку вчителя початкових класів, є модернізація педагогічної практики у відповідності 3 трьома моделями: педагогічна практика відіграє підпорядковану роль; у ході практики студенти оволодівають тільки методичними прийомами; студенти оволодівають аналітичною педагогікою і методичними прийомами.

У німецьких вищих навчальних закладах спостерігається стійка тенденція до скорочення лекційних занять і збільшення семінарських. Практикується підготовка до проведення семінарів самими студентами, індивідуальна форма роботи зі студентами посідає все важливіше місце в навчальному процесі.

Аналізуючи досвід педагогічних вищих навчальних закладів різних країн 3 професійної підготовки вчителів початкових класів, можна виявити такі тенденції вдосконалення навчання студентів:

- психолого-педагогічна і соціологічна спрямованість змісту педагогічної освіти;

- практична підготовка майбутнього вчителя до спілкування на основі тренінгових занять;

- реформування педагогічної практики;

- використання практико-орієнтованих форм навчання: мікровикладання, моделювання навчальних ситуацій, аналіз відеофрагментів уроків, шкільні та лабораторні практикуми;

- використання інформаційних технологій;

- підвищення ролі самостійної підготовки студентів.

Розглянутий досвід підготовки вчителів початкових класів дозволяє нам визначити такі умови модернізації професійної підготовки вчителя початкових класів у системі вищої педагогічної освіти: розроблення теоретичних моделей діяльності вчителя початкових класів нового типу; обгрунтування критеріїв особистіснопрофесійного розвитку майбутнього вчителя початкових класів; розроблення моделі забезпечення продуктивного особистісно-професійного розвитку майбутнього вчителя початкових класів; виявлення педагогічних умов, що лежать в основі ефективного реформування навчально-виховного процесу; мобільність і варіативність вибору студентом рівня професійної кваліфікації, додаткової спеціальності, спеціалізації, що забезпечить побудову індивідуальної освітньої стратегії.

\section{Література}

1. Артюшина М. В. Інноваційний підхід у викладанні психолого-педагогічних дисциплін у вищих навчальних закладах освіти України / М. В. Артюшина // Вісник НТУУ «КПІ». Філософія. Психологія. Педагогіка. -2009. - Випуск 3. 2. Васянович Г. П. Педагогіка і психологія/ Григорій Петрович Васянович// Васянович Г. Вибрані твори: в 5-ти т. - Т. 4: Збірник наукових праць. - Львів : Сполом, 2010. - 512 c. 3. Гончаренко С. Фундаметналізація освіти як дидактичний принцип / Семен Гончаренко // Шлях освіти. - 2008. - № 1. - С. 2-6. 4. Кустовська О. В. Методологія системного підходу та наукових досліджень: курс лекцій / О. В. Кустовська. - Тернопіль: Економічна думка, 2005. - 127 с. 
5. Митина Л. Н. Личностное и профессиональное развитие человека в новых социально-экономических условиях / Л. Н. Митина // Вопросы психологии. - 1977. № 4 -С. 29-32. 6. Онищук Л. А. Фундаментальність - категорія якості освіти та освіченості сучасної людини / Л. А. Онищук// Шлях освіти. - 2011. - № 2 (60). C. 15-20.

\section{АНАЛІЗ СТАНУ ПРОБЛЕМИ РОЗВИТКУ ПРОФЕСІЙНО ЗНАЧУЩИХ ЯКОСТЕЙ УЧИТЕЛЯ ТЕХНОЛОГІЇ В ПІСЛЯДИПЛОМНІЙ ОСВІТІ}

Ковальчук I. М. Аналіз стану проблеми розвитку професійно значущих якостей учителя технології в післядипломній освіті.

У статті виявлено та проаналізовано результати стану обізнаності вчителів щодо сутності, змісту сучасних професійно значущих якостей учителя технології й методів їх розвитку та рівень готовності вчителя технології до професійного самовдосконалення. Визначено, що в переважної більшості вчителів технології наявний розрив між бажанням бути фахівцем своєї справи і реальними здібностями в досягненні зазначеної мети, між зовнішнім прагненням учителя до професійного зростання та відповідним достатнім рівнем внутрішньої мотивації.

Ключові слова: професійно значущі якості, технологічні якості, самовдосконалення, мотивація, самооцінка.

Ковальчук И. М. Анализ состояния проблемы развития профессионально значимых качеств учителя технологии в последипломном образовании.

В статье определены и проанализированы полученные результаты представлений учителей о сущности, содержании современных профессионально значимых качеств учителя технологии, методах их развития, а также уровень мотивационной готовности учителя технологии к профессиональному самосовершенствованию. Определено, что в подавляющем большинстве существует разрыв между желанием учителей технологии быть профессионалом своего дела и реальными способностями в достижении этой цели, между внешним стремлением учителя к профессиональному росту и соответствующим достаточным реальным уровнем внутренней мотивации.

Ключевые слова: профессионально значимые качества, технологические качества, самосовершенствование, мотивация, самооценка.

Kovalchuk I. M. The analysis into the problem of developing professionally significant qualities of a Technology teacher in postgraduate education.

The article defines and analyzes the obtained results as for teachers' idea about the gist and meaning of present-day professionally significant qualities of a Technology teacher, methods of their development as well as the level of motivational readiness of a Technology teacher to professional self-perfection. The author determines that in most cases there is a gap between a Technology teacher's desire to be an expert in his/her sphere and actual abilities to reach the goal, between teacher's outward urge towards professional selfperfection and relevant level of inward motivation

Key words: professionally significant qualities, technological qualities, self-perfection, motivation, self-appraisal. 